\title{
THE ENVIRONMENTAL ADDED VALUE OF WATER: A PROPOSAL
}

\author{
ALFONSO G. BANDERAS TARABAY \& REBECA GONZÁLEZ-VILLELA \\ Mexican Institute of Water Technology (IMTA), Mexico.
}

\begin{abstract}
This work develops a proposal to assign an added value to the water used by man in various productive processes. The cost of energy needed to evaporate a cubic meter under natural conditions is multiplied by the lowest local price per kWh to calculate an 'intrinsic value' of water (IVW). The resulting amount constitutes the monetary unit that is applied to calculate an added value on an entirely environmental basis, regardless of the law of supply and demand and the subjectivity prevailing in the market. Then, it is necessary to calculate the volume required to return to the used water the quantity and quality it had before the production process, or the dilution volume necessary for the wastewater to comply with the corresponding ecological standard for a particular pollutant (indicator). This amount is called the 'restitution volume' (RV), and the product (IVW x RV) constitutes the proposed environmental added value (WEAV). A table showing the evaluation of RV for a set of production processes is included. Several examples are developed to calculate the price of water in this context, including the human right to water and nature conservation, for which it is necessary to include some local costs of the regular water service, such as the federal and municipal costs of construction, operation, maintenance, and administration (COMA) of infrastructure: Water price $=$ IVW + federal COMA + municipal COMA + WEAV, in which IVW represents a payment for the environmental services of the water within the hydrological cycle, such as the support of animal and plant production in the biosphere, climate regulation and shielding against UV rays. A brief discussion on the advantage of this methodology to ensure environmental and human rights to water is included.
\end{abstract}

Keywords: cost, ecological added value, price, uses, water evaporation heat.

\section{INTRODUCTION}

The advance of 'civilization' has caused the global deterioration of natural resources and biodiversity, which has led to several international meetings aimed at establishing agreements among countries to take the necessary measures to halt and, as far as possible, to revert natural and social degradation, which is evident and even alarming in many parts of the world Wright and Nebel [1].

Physical causes of deterioration in developing countries are the over-exploitation of natural resources, the production of large quantities of sewage and garbage, and the emission of greenhouse gases into the atmosphere. Behind these physical causes is the economic cause, represented by the gross domestic product of each country, which is an indicator of its economic prosperity and serves as a guarantee for international loans and investments, requested with the aim of promoting 'development' Stern [2].

Water is among the resources affected by deterioration in spite of the fact that it is a fundamental resource for life on the Earth. Over $90 \%$ of all visible living matter is plant life. Plants build and renew their tissues - about 25 billion tons annually - through photosynthesis, which combines oxygen obtained from water molecules with environmental carbon dioxide molecules to form carbohydrate molecules and release molecular oxygen to the environment, which is as necessary as water for life Niklas and Spatz [3]; Banderas and Gonzalez-Villela [4].

In addition, water is not an ordinary resource, such as cotton, wood, iron, or petroleum, which can be substituted in many applications by synthetic products, but with all the environmental problems involved in such substitution EEA [5], which affects its value in a free market 
economy. Water has an irreplaceable function for life; hence, it should not be subject to a market economy nor be transferred to private companies Barlow and Clark [6-8].

Moreover, the considerations necessary to determine a fair water price are different between northern and southern countries, mainly because in the latter ones water is frequently limited by its heterogeneous distribution, arid conditions and growing competition for it among individuals, communities, and states Anton [9]; Solis [10], resulting in very variable prices that allow for speculation, as will be seen in Table 2 .

The values proposed in this paper are taken out from such a commercial context to present an assessment of water and its uses based on purely physical and chemical concepts: 1) the energy required to mobilize it through the hydrological cycle, which enables it to maintain natural phenomena and its use for human consumption; and 2) the relation of concentrations of some chemical indicator of water quality between the influent to the productive process and the effluent with the residual water.

To this end, an intrinsic water value (IVW) Banderas and Gonzalez-Villela [4] will be applied, calculated on the basis of a unique characteristic of water, its latent heat of evaporation (hence its 'intrinsic' character), measured at $27^{\circ} \mathrm{C}$, the critical temperature of sea water at which the formation of hurricanes begins Anthes [11], being these last one of the most important water sources for the country Prieto et al. [12].

On the other hand, it is common to evaluate the cost-benefit ratio when humans access natural resources, but the cost to nature of human activities is rarely evaluated, and even less the benefit to nature of those activities (if any). In this alternative, an environmental added value (WEAV) is proposed for the water used in several production processes in a purely environmental context, related to the restitution of the quantity and quality of the water before being used, without involving commercial considerations. This WEAV reflects the cost to nature of the degradation of the volume of water used in human productive activities.

With this approach, the authors take the place of the entity affected by the so-called demophoric explosion by Vallentyne [13], which is the same that provides water: nature. At the same time, they help nature impose the price of its environmental and productive services. The importance of IVW is to help nature translate these processes into a monetary base.

The exercise of eliminating value judgments and market laws of the water price is done since they could interfere with the human and environmental rights to this commodity, especially where it is scarce; so that the price only includes service costs, such as construction, operation, administration, and maintenance (COMA) of the infrastructure, whose prices are unitary and therefore auditable, as well as IVW and WEAV, and to show how the human economy is not very different from nature's economy, even when the COMAs, which are usually subject to speculation, are eliminated.

\section{BACKGROUND}

Mexico receives an annual rainfall volume of $1,489 \mathrm{~km}^{3}$. Evaporation returns $1,065.994 \mathrm{~km}^{3}$ (71.6\%) to the atmosphere; infiltration accounts for $92.3 \mathrm{~km}^{3}(6.2 \%)$; leaving $471 \mathrm{~km}^{3}$ $(31.6 \%)$ of available water CONAGUA [14]. To evaporate this rainwater, each year the Sun introduces $3.63 \times 10^{12} \mathrm{MJ} \mathrm{yr}^{-1}$ or $1.01 \times 10^{12} \mathrm{~kW} \mathrm{~h} \mathrm{yr}^{-1}$ of energy to Earth's surface. This amount of energy is multiplied by the electric service rate to translate it into money (Solar Financing), resulting in about US\$46 billion [3], which serves to give an anthropocentric measure, on physical bases, of what the human species owes nature for water.

The IVW (US \$ 0.031) is obtained by dividing the Solar Financing by the total volume of precipitation, and represents the cost of nature to distill a cubic meter of water by means of 
solar radiation, in the physiographic conditions of the country, and which subsequently precipitates as clean water conserving all its potential uses [4]. From the practical point of view of this paper, the IVW would be representing the human right to satisfy the vital water requirement.

This value is the first investment made by nature for the benefit of life on the planet, including the environmental services of evaporated volume.

The capital gain or added value (in Spanish: plusvalía = Increased value of something for reasons extrinsic to it [15]), varies greatly. For example, the value of a given volume of water may not be the same if used for:

- Washing and personal hygiene than for doing business with water (bottling and use in hotels, public baths, restaurants, and spas)

- Watering crops for self-consumption than for selling them

- Irrigating crop fields than for irrigating a golf course

- Operating a hydroelectric plant than for operating a thermoelectric plant

- Recreational purposes than for fish farming

These cases are presented on a decreasing scale of real basic needs that are compared with commercial and sumptuary uses through value judgments [16], which are accentuated under conditions of scarcity. The authors of the present paper think that human rights to water, food, and a healthy environment must be separated from value judgments and be evaluated objectively on physical bases.

Sumptuary value applications should consider a surcharge to the rent derived from the cost of basic COMA. For example, an aqueduct built to provide drinking water to a city cannot generate the same income as one used for a thermoelectric plant or for oil fracking; furthermore, the latter apparently implies a huge ecological and environmental risk [17].

\section{METHODOLOGICAL CONSIDERATIONS}

The method described here uses three measurable quantities: 1) the volume used for any purpose; 2) the volume of restitution (VR), where restitution is defined as: 'to set up again; the making good of or giving an equivalent for some injury' [18] and 3) the IVW. Thus, value judgments and speculation are avoided when calculating the surcharge on luxury uses, fines and transactions.

Conservation areas under federal or municipal control fed by rainwater are exempt from environmental added value, as wilderness areas, unless they are under some form of exploitation. Those using surface and groundwater should calculate their volumes and the environmental flows required by law and observe their application by defining the amount, frequency, and timing of environmental flows Richter et al. [19]. However, this does not exempt from paying the respective COMAS if they have to use some kind of aqueduct.

Environmental added value for hydroelectric power generation includes two components: the change in water quality of the reservoir due to the damming, which is reflected in its trophic status [20], and the volume evaporated as a result of increased evaporation surface when the river enters the reservoir $(\Delta \mathrm{Vev})$. The former is measured with an adequate water quality indicator $\left(\mathrm{X}_{2}\right)$, such as biochemical oxygen demand (BOD), total nitrogen, or total phosphorus [19], and then divided between the same in the river $\left(X_{2} / X_{1}\right)=k$. This quotient represents the number of times that the water in the reservoir must be diluted to return to the quality it has in the river. The restitution volume is equal to $\mathrm{k}$ multiplied by the reservoir volume. 
Finally, the environmental added value of the hydroelectric generation is obtained by multiplying the IVW by the sum of the restitution volumes resulting from both evaporation and water quality.

This procedure can also be applied to lakes and rivers affected by cultural eutrophication [20], that is, wastewater discharges from communities that inhabit their catchment and river basins.

In other production processes, the appropriate indicator of contamination in the sewage should be sought, and the RV is calculated in relation to the ecological level allowed by the local environmental norm with respect to this contaminant. RV is the amount of water needed to return it to the quality it had before passing through the production process. To do this, a physical, chemical, or biological indicator showing the quality change due to the production must be selected [21]. This procedure would apply in the case of large cities that do not separate gray waters from sewage, as well as for industrial and fracking purposes.

If this indicator is not in the water before passing through the production process, it should be excluded and whoever includes it will be sanctioned until a way is found to remove it from its effluent. These indicators have different weights in different industries, and the most synergistically pernicious, the most toxic to life (polluting type) and that of higher concentration Ostrander [22] should be preferred. There will be the option of investing in treatment to avoid the fine and closure and to minimize payment for environmental gain.

In the case of aquaculture [23]: for self-consumption in river water that does not require infrastructure, the IVW should only be paid by the estimated production volume per unit weight of the exploited species. If stagnant water is used, the IVW should be paid for the used volume; evaporation is not paid, although it can be high; if additional infrastructure is required, the municipal COMA should be paid; commercial aquaculture pays IVW by the volume of water, plus the federal (and/or municipal) COMA and the environmental added value due to changes in volume and water quality.

The environmental added value of water for different types of irrigation contains the same elements; the difference lies in the volume used, the evaporation measured during the agricultural cycle, and the type and quantity of agrochemicals applied. Irrigation by technological means, which uses less water, will be cheaper, which will stimulate their proliferation and facilitate their efficient use. Organic agriculture minimizes WEAV, since it does not apply agrochemicals FAO [24], and therefore does not pollute the receiving water bodies of agricultural return water, rather than with sediment.

Public parks and sports facilities only pay the IVW, the municipal COMA, and evaporation, but sumptuary commercial irrigation, which is used for business-including golf courses and private sports courts - must pay a premium, multiplying the IVW by the number of square (or cubic) meters of development.

In the case of livestock, urban, touristic and industrial uses, the criterion is the same; the only thing that varies is the indicator of water quality before and after the development. In the case of intensive farming, the drains are identifiable. In ranching, the pollution of the environment, surface runoff, groundwater and evaporation in the troughs should be estimated. Small urban settlements without industry will pay an added value relating to BOD, with the option of investing that capital in treatment infrastructure to reduce payment to a minimum. This option is valid for all productive processes.

In the case of fines and penalties for the misuse of water, or for providing defective services, the respective environmental added value must be paid. For example, in the case of the Sonora River [25], data from the Water Quality Monitoring Network [14], obtained on or as 
close as possible to the site before the event, should be consulted and compared with assessments on the site after the incident, calculating the concentration difference regarding quality at the affected site. This should be done in several places at the edge of the incident, and environmental added value should be calculated, that is, the volume necessary to restore the quality of the aquatic ecosystem before the event. This restitution volume is multiplied by the IVW to calculate the amount of the fine. This penalty shall apply notwithstanding the other impacts to terrestrial ecosystems and human populations.

If federal and/or municipal infrastructure is used, the respective COMA must be charged. In Mexico, there are approximately 4,462 storage dams and levees, 6.5 million hectares of irrigated land, 2.9 million hectares of technified rain-fed land, 631 water treatment plants in operation, 2,029 municipal wastewater treatment plants in operation, 2,186 industrial wastewater treatment plants in operation, and more than 3,000 km of aqueducts [14]. The administration and operation expenses include wages and energy costs.

Fines and penalties for overexploited or contaminated aquifers will directly depend on the depth to which the aquifer is harmed. If the damage is on an intermediate or regional flow $[26,27]$ it will result in the cancellation of the water allocation and the decommissioning of facilities.

\section{RESULTS}

The water added value should increase according to the non-exhaustive scale shown in Table 1.

The Vital Human category, which is to meet the daily individual water requirement, is about 4 to $6 \mathrm{~L}$ per day per person [28]. Considering $5 \mathrm{~L}$ for 120 million people, that is $600 \times 10^{6} \mathrm{~L} \mathrm{a}$ day $=0.219 \mathrm{~km}^{3}$ a year. It is a negligible portion of the annual $\mathrm{Vp}$ and $0.046 \%$ of the available volume. The water needed to meet other basic human requirements, such as washing and personal hygiene, vary according to personal habits and region. On a base of $100 \mathrm{~L}_{\text {individual }}{ }^{-1}$ day $^{-1}$, it would be $4.38 \mathrm{~km}^{3}$ a year, or $0.93 \%$ of the available volume. Mexicans should pay, for the first concept, US $\$ 4.03$ million a year (Table 4 considers only payment for the IVW), and for the second one US\$302 million a year, or US\$2.55 per inhabitant a year (the proposed payment is IVW plus federal COMA). This is the current fee paid every two months for minimum domestic consumption (2015 prices).

If municipal COMA is used, with a mean value of US\$0.8 per cubic meter [29], the last amount increases to US\$32.7 per inhabitant per year. It can clearly be seen that municipal costs increases the price of water. These costs vary greatly in the country due to the commercial added value (Table 2); therefore, the correct COMA should be calculated, which should be close to that of humid areas (US\$0.2), where speculation is minimal, because water is abundant. Thus, the payment is reduced to a quarter (US\$8.00 per inhabitant per year), which is a reasonable amount considering the country's economy, with an average per capita income of US\$ 6,000 INEGI [30].

Roughly, local agriculture produces almost $200,000 \mathrm{~T} \mathrm{y}^{-1}$ of crops and accounts for $77 \%$ of the water consumed in the country: 20.76 groundwater +41.04 surface water $=61.8 \mathrm{~km}^{3}$. The evaporation of this volume requires $42 \times 10^{9} \mathrm{~kW} \mathrm{~h} \mathrm{yr}^{-1}$, which correspond to an IVW of US\$ 1.9 billion $\mathrm{yr}^{-1}$ for environmental services. However, $50 \%$ is lost by evaporation during the production process, so its WEAV is a half of the latter amount: US\$ 0.95 billion $\mathrm{yr}^{-1}$, giving a total of US $\$ 2.85$ billion. To get an idea of the benefit provided for this WEAV, the sale of exported agricultural products reached US\$24.4 billion in 2013 [31, 32], more than 25 times the amount of 0.95 billion. This, supposing we are dealing with organic agriculture that does 
Table 1: Prices proposed for water for different uses.

\begin{tabular}{|c|c|c|c|c|c|}
\hline \multirow{3}{*}{$\mathbf{I}$} & \multirow{3}{*}{$\begin{array}{l}\text { Use } \\
\text { As a human right }\end{array}$} & \multicolumn{4}{|l|}{ Rate } \\
\hline & & \multirow[t]{2}{*}{ WEAV } & \multirow[t]{2}{*}{ IVW } & \multicolumn{2}{|c|}{ COMA } \\
\hline & & & & $\mathrm{F}$ & M \\
\hline 1 & Vital Human & - & $\mathrm{x}$ & & \\
\hline 2 & Basic Human & - & $\mathrm{x}$ & $\mathrm{x}$ & \\
\hline II & Nature Conservation & & & & \\
\hline 3.1 & Municipal, state & - & $\mathrm{x}$ & $\mathrm{x}$ & \\
\hline 3.2 & National & - & $\mathrm{x}$ & $\mathrm{x}$ & \\
\hline III & As a natural resource & & & & \\
\hline 4 & Subsistence fish farming & - & $\mathrm{x}$ & & \\
\hline 5 & Hydropower generation & $=\mathrm{f}(\Delta \mathrm{BOD}+\Delta \mathrm{Vev})$ & $\mathrm{x}$ & $\mathrm{x}$ & \\
\hline 6 & Thermoelectric generation & $=\mathrm{f}(\Delta \mathrm{T}+\Delta \mathrm{COD}+\Delta \mathrm{Vev})$ & $\mathrm{x}$ & $\mathrm{x}$ & \\
\hline 7 & Commercial fish farming & $=\mathrm{f}(\Delta \mathrm{BOD}+\Delta \mathrm{Vev})$ & $\mathrm{x}$ & $\mathrm{x}$ & \\
\hline 8 & Subsistence flood irrigation & $=\mathrm{f}(\Delta \mathrm{N}, \mathrm{P}+\Delta \mathrm{COD}+\Delta \mathrm{Vev})$ & $\mathrm{x}$ & & $\mathrm{x}$ \\
\hline 9 & Subsistence modern irrigation & $=\mathrm{f}(\Delta \mathrm{N}, \mathrm{P}+\Delta \mathrm{COD}+\Delta \mathrm{Vev})$ & $\mathrm{x}$ & & $\mathrm{x}$ \\
\hline 10 & Commercial rolled irrigation & $=\mathrm{f}(\Delta \mathrm{N}, \mathrm{P}+\Delta \mathrm{COD}+\Delta \mathrm{vVev})$ & $\mathrm{x}$ & $\mathrm{x}$ & $\mathrm{x}$ \\
\hline 11 & Commercial modern irrigation & $=\mathrm{f}(\Delta \mathrm{N}, \mathrm{P}+\Delta \mathrm{COD}+\Delta \mathrm{Vev})$ & $\mathrm{x}$ & $\mathrm{x}$ & $\mathrm{x}$ \\
\hline 12 & Comm sumptuary irrigation* & $=\mathrm{f}(\Delta \mathrm{BOD}+\Delta \mathrm{COD}+\Delta \mathrm{Vev})$ & $\mathrm{nx}$ & $\mathrm{x}$ & $\mathrm{x}$ \\
\hline 13 & Public parks and sports facilities & $=\Delta \mathrm{Vev}$ & $\mathrm{x}$ & & $\mathrm{x}$ \\
\hline 14 & Subsistence livestock & $=\mathrm{f}(\mathrm{BOD})$ & $\mathrm{x}$ & $\mathrm{x}$ & \\
\hline 15 & Commercial livestock & $=\mathrm{f}(\mathrm{BOD})$ & $\mathrm{x}$ & $\mathrm{x}$ & $\mathrm{x}$ \\
\hline 16 & Urban/municipal service & $=\mathrm{f}(\mathrm{BOD}+\mathrm{COD})$ & $\mathrm{x}$ & $\mathrm{x}$ & $\mathrm{x}$ \\
\hline 17 & Tourism/recreational services & $=\mathrm{f}(\mathrm{BOD})$ & $\mathrm{x}$ & $\mathrm{x}$ & $\mathrm{x}$ \\
\hline 18 & Industrial services & $=\mathrm{f}(\Delta \mathrm{X}, \mathrm{Y}+\mathrm{COD}+\Delta \mathrm{Vev})$ & $\mathrm{x}$ & $\mathrm{x}$ & $\mathrm{x}$ \\
\hline 19 & Commercial transactions & $=\mathrm{V}$ & $\mathrm{x}$ & $\mathrm{x}$ & $\mathrm{x}$ \\
\hline 20 & Fines: waste or pollution & $=$ respective $\Delta \mathrm{V}$ & $\mathrm{x}$ & $\mathrm{x}$ & $\mathrm{x}$ \\
\hline 21 & Groundwater extraction & $=\mathrm{f}(\mathrm{Vev})$ & $\mathrm{x}$ & $\mathrm{x}$ & $\mathrm{x}$ \\
\hline
\end{tabular}

COD, BOD $=$ Chemical and biochemical oxygen demand [19].

$\Delta(\mathrm{T}, \mathrm{N}, \mathrm{P}, \mathrm{X}, \mathrm{Y})=($ influent - effluent $)$ temperature difference or the appropriate water quality indicator.

$\Delta \mathrm{V}=$ Volume.

$\Delta \mathrm{Vev}=$ Evaporated Volume.

$\triangle \mathrm{COD}=$ (influent - effluent $) \mathrm{COD}$ difference or the appropriate water quality indicator.

$\triangle \mathrm{BOD}=$ (influent - effluent) BOD difference or the appropriate water quality indicator. $\mathrm{Av}=$ Added value: The volume of water required to achieve the original water quality or the level permitted by the respective ecological standard, multiplied by the IVW.

* =Applies to private property (tennis courts and water and other sports facilities, including golf).

$\mathrm{n}=$ Developed area in square meters. 
Table 2. Production costs and water rates in some cities randomly selected on the North (Tijuana) - South (Tuxtla Gutierrez) gradient [29].

\begin{tabular}{llllll}
\hline$\#$ & City & $\begin{array}{l}\text { Cost } \\
\text { MX\$ }\end{array}$ & $\begin{array}{l}\text { Rate } \\
\text { MX\$ }\end{array}$ & $\begin{array}{l}\text { Difference } \\
\text { MX\$ }\end{array}$ & $\begin{array}{l}\text { Difference } \\
\text { average }\end{array}$ \\
\hline 1 & Tijuana & 9 & 21 & 12 & \\
2 & Monterrey & 9.5 & 12.5 & 3 & \\
3 & Aguascalientes & 7 & 12 & 5 & \\
4 & León & 10.3 & 18.6 & 8.3 & $\mu=6.53 / 4.83$ \\
5 & Pachuca & 7.4 & 11.3 & 3.9 & \\
6 & Mexico City & 8 & 15 & 7 & \\
7 & Puebla & 8 & 11.50 & 3.5 & \\
8 & Xalapa & 7.32 & 12 & 4.7 & \\
9 & Cuernavaca & 5 & 8.8 & 3.8 & \\
10 & Mérida & 4 & 6 & 2 & \\
11 & Tuxtla Gutierrez & 6 & 14 & 8 & \\
\hline
\end{tabular}

not contaminate the water of agricultural return by agrochemicals, nor that the water comes from a dam. If agrochemicals are used and/or there is a dam, the WEAV must be adjusted as we have seen before.

Groundwater agriculture deserves further comment. Crop production began to depend on groundwater until very recently in human history, with a boom in the past century Shah [33]. It is estimated that $97 \%$ of the country's water lies underground, but the number of overexploited aquifers is increasing, because arid zones occupy almost $70 \%$ of the country [14], Diaz-Padilla et al. [34]. To calculate the environmental added value for almost $20.76 \mathrm{~km}^{3}$ extracted annually, it should be considered that, once on the surface, groundwater is subject to infiltration, runoff, and a more intense evaporation (almost 90\%), due to aridity, before and after use, and becomes part of the hydrological cycle. Therefore, this vapor is increasing the potential for rain, which eventually will fall in wet areas prone to more frequent flooding due to global warming [12]. In this case, modernization could apparently increase irrigation efficiency and reduce WEAVE, but the increased frequency and intensity of floods have disastrous effects for mankind.

\section{DISCUSSIONS}

So far, the ideas developed in this paper draw a picture in which water is no longer a simple natural resource that can be marketed and an excuse to collect money, it becomes a dynamic entity that interacts with the human economy by its irreplaceable vital character and its own dynamics, that man must respect and preserve to ensure water supply in the future.

The IVW is included as a fixed fee per volume unit representing the intrinsic value of water, which is currently immeasurable due to its vital function both inside and outside living things. The volumetric IVW, so-called Solar Financing, together with the proposed environmental added value (WEAV), calculated from the Restitution Volume (RV), allows to estimate nature's investment in environmental services and the cost to nature of human activities in a purely environmental context, related to the restitution of the quantity and quality of water 
before being used, without involving commercial considerations. This WEAV reflects the cost to nature of the degradation of the volume of water used to support human development.

The WEAVE is a natural added value calculated and applied in this paper to estimate the value of water volumes exchanged between man and nature, but it can also be applied to calculate fines for wasting, misusing, or polluting water, or for having defective infrastructure affecting administration and electricity costs, as well as human and environmental wellness. They could be included in the price given to each unit volume offered to the public. This is:

$$
\$=\text { IVW + COMA fed. + COMA municipal + WEAV. }
$$

Excepting the IVW and the WEAV, the components of this equation vary depending on management costs and the type and use of infrastructure, but these are perfectly controllable through unit cost rates and audits, thus avoiding the introduction of charges for spurious items (such as speculation), that are not strictly derived from the environment care.

IVW refers to unpaid ecosystem services, and WEAV is a function of the environmental impact indicators related to use. Therefore, it does not lend itself to speculation, which is very convenient if it is to satisfy the human right to water and sanitation, recognized by the United Nations General Assembly through Resolution 64/292 of 28 July 2010. It "calls upon States and international organizations to provide financial resources, to promote training and technology transfer to help countries, in particular developing countries, to provide a supply of drinking water and healthy, clean sanitation', and the General Comment No. 15 on the right to water-adopted by the Committee on Economic, Social and Cultural Rights in November 2002, set out in Article I.1—states: 'The human right to water is indispensable for a dignified life', and defines the right of everyone to sufficient, healthy, physically acceptable and affordable water for personal and domestic use. Furthermore, the United Nations Development Program suggests that the cost of water should not exceed 3\% of family income.

To meet this objective in a simple and clear way, the price of consumption of a given volume must be the same regardless of the region, which is justified because the money raised should apply to different works and priority actions that depend on the local availability of water. That is, water service comprises: containment, diversion, capture and/or removal, storage, treatment, distribution, use, treatment, disposal, 2nd treatment and recycling. In arid areas, the last three stages are a priority and occur after human use, since the efficiency of a given volume increases due to recycling, while in humid areas there are two stages that occur before use (containment and diversion), especially during the rainy season. In addition, treatment in humid areas becomes more important because environmental conditions are favorable for the development of pests and diseases and requires more attention because local urban infrastructure and water and sanitation systems are inadequate [14].

In this same sense, the above-calculated payment of US\$8.00 per inhabitant per year is a reasonable amount considering the country's economy. The authors consider that all people must pay for the water they consume. Giving free water to those who have less is equivalent to re-labeling them as marginalized, which would demonstrate a lesser human quality of those responsible for promoting development, as mentioned in a previous paragraph.

That is, with the exchange rate of 2015 , the Mexican people (120 million) should pay USD 305 million per year for their basic and vital water consumption. The income in one year of many professional athletes and actors in the USA and Europe is close to this amount. 
Therefore, developed countries would have no problem in giving this money to developing countries, but that is not the solution to marginalization. To many native peoples, water has fallen from the sky for generations. So, the real problems of marginalization are:

1. The historical appearance of fences, walls, alarms, dogs, and even weapons and ideologies that prevent access to areas in which their ancestors found daily sustenance,

2. In developing countries, the diversion of economic resources is more the rule than the exception IT [35], IMCO [36].

The solution to these problems requires, in the first case, education and better legislation. In the second case, greater supervision of the application of national and international economic resources is required, to avoid losses and direct investments to where they are most needed, to create jobs and income for people to have resources to pay for many things besides water. That is, eliminate poverty, and in the case of disabled persons (abandoned elderly, the mentally ill, the homeless), water consumption would be paid by public and private foundations.

\section{FINAL CONSIDERATIONS}

1. The IVW is a commercial value calculated without prejudice, so it could be a fair, invariable and naturally fair price and a reasonable amount that would guarantee the human right of access to water in sufficient quantity and quality to cover basic needs. Its application would stimulate the optimal functioning of the network of hydrometric stations in the country. The capital raised by this concept would be used for projects of scientific and technological research that would result in works and actions for conserving the volume and quality of water in natural ecosystems - because if the environment falls, there is no water-and to buffer the effects of climate change. The money collected applying the WEAV to fines and penalties would be applied to transparent management and to disseminate updated knowledge on water.

2. If the IVW were to be charged for all precipitated water in the country, a very large amount would be collected, enough to pay (if nature would charge it) for the environmental services provided by the water to maintain an adequate biosphere.

3. In the unlikely event that the government can raise the money for the payment of IVW of available water (31.6\% of $\mathrm{Vp}$ ), which is impossible given its uneven distribution and lack of service coverage and high demand of users (except natural ecosystems), the capital could cover the combined budgets of the CONAGUA and SEMARNAT (Water and Environment and Natural Resources Bureaus) in 2016, both fused and dedicated to caring together, directly and indirectly, technical and naturally, the quantity and quality of territorial water.

4. The proposed WEAV has several advantages if it is applied to water service rates without involving value judgments regarding the necessity and convenience [10]: it can be added to the cost of collection, processing, distribution, maintenance, and expansion of the network; to fix the amount of the transactions or exchanges of water volumes between individuals, communities, areas, regions or basins; to calculate the amounts of fines for waste, pollution or misuse of water; or to sanction any defective infrastructure that does not fulfill its mission.

5. In addition, the IVW allows estimating a monetary value for the so-called water footprint by Hoekstra [37]. 


\section{PROSPECTS FOR RESEARCH}

Three issues should be noted:

1. Hydrological data vary over the years due to climate variability. In addition, as global warming promotes evaporation, a greater potential of rain in wetlands and greater aridity in dry areas is expected. It would be necessary to agree on which mean values should be considered in order to obtain precise calculations.

2. It is necessary to complement Table 1 with the greater quantity of productive activities and its WEAV proposed.

3. A study should be conducted to assess the feasibility of this proposal, which would require changing the economic paradigms in a market economy of water for a 'natural economy of water.'

\section{REFERENCES}

[1] Wright, R.T. \& Nebel, B.J., Environmental science: toward a sustainable future. 10th Ed. Pearson/Prentice Hall, 2008.

[2] Stern, N., The economics of climate change: the stern review, Cambridge University Press: UK, 2008.

[3] Niklas, Karl J. \& Spatz, H-C., Plant physics. The University of Chicago Press; USA, 2012.

[4] Banderas, A. \& González-Villela, R., The intrinsic value of water: A proposal. WIT Transactions on Ecology and The Environment, 200, pp. 137-145, 2015. https://doi.org/10.2495/WS150121

[5] European Environment Agency. Environment in the European Union at the turn of the century. Office for Official Publications of the European Communities, Elsevier Science Ltd, Luxemburg, 2001 (Spanish version).

[6] Barlow, M. \& Clark, T., Blue gold: the fight to stop corporate theft of the world's water. The New Press, 2002 (Spanish version).

[7] Transnational Institute (https://www.tni.org/en/publication/here-to-staywa ter-remunicipalisation-as-a-global-trend). Consulted 18/01/2017.

[8] Freshwater Organization, available at: http://freshwater.org/wp-content/uploads/ joomla/ PDFs/critical-water/valueofwater.pdf. (accessed 18 January 2017).

[9] Anton, D.J., Thirsty cities: urban environment and water supply in Latin America. International Development Research Center, Ottawa: Canada, 1993.

[10] Solís, L., La Escasez, el Costo y el Precio del Agua en México. El Colegio de México: Mexico, 2005.

[11] Anthes, R.A., Tropical cyclones: their evolution structure and effects. Meteorological Monographs, 19(41), 1982.

[12] Prieto, R., Ramírez, R., Cortés, V. E. \& Maya, M.E., Impacto del cambio climático en la temporada de lluvias en México. In P. F. Martínez-Austria \& C. Patiño-Gomez (Eds.), Atlas de vulnerabilidad hídrica en México ante el cambio climático. Semarnat-IMTA, Cap. 3, pp. 65-80. 2010.

[13] Vallentyne, J.R., Freshwater supplies and pollution: Effects of the demophoric explosion on water and man. In N. Polunin (ed.), The environmental future. Macmillan Press Ltd, London: UK, pp. 181-211, 1972.

[14] National Water Comission (CONAGUA). Sistema Nacional de Información del Agua (SINA) - Estadísticas del Agua en México 2011, México (http://www.cna.gob.mx/ Contenido.aspx $? \mathrm{n} 1=3 \& n 2=60 \& n 3=87 \& n 4=30$ ). (accessed 15 April 2016). 
[15] Real Academia de la Lengua Española, Diccionario de la Lengua Española. 22 ${ }^{\mathrm{a}}$ Edición, Tomo II. Madrid: Esp. 2002.

[16] Raucher, R., The value of water: What it means, Why it's important, and How water utility managers can use it. Journal AWWA, 97(4), pp. 90-98, 2005.

[17] Available at: http://www.greenpeace.org/espana/Global/espana/report/cambio_climatico/Fracking-GP_ESP.pdf

[18] Webster's Third New International Dictionary. Merriam Webster Inc. USA. V: II. 1986.

[19] Richter, B.D., Warner, A.T., Meñyer, J.L. \& Lutz, K., A collaborative and adaptive process for developing environmental flow recommendations. River Research and Applications, 22, pp. 297-318, 2006. https://doi.org/10.1002/rra.892

[20] Straskraba, M., Tundisi, J. \& Duncan, A., Comparative reservoir limnology and water quality management, Kluwer Academic Publishers, Dordrecht: The Netherlands, 1992.

[21] American Public Health Association (APHA), Standard methods for the examination of water and wastewater, APHA, AWWA, WEF, Washington DC, 2012.

[22] Ostrander, G.K., Tecniques in aquatic toxicology, CRC Press, Inc. USA, 1996.

[23] Wheaton, F.W., Aquacultural engineering. Wiley, USA. 1977. First Spanish Edition AGT Ed. D.F. México, pp. 704, 1982.

[24] FAO, Organic Agriculture, Committee on Agriculture, Fifteenth Session, Item 8 of the Provisional Agenda. Rome, Red Room. January 25-29, 1999. Available at: http://www. fao.org/docrep/meeting/X0075e.htm. (accessed 02 January 2017).

[25] Carretto, B., A 2 años del derrame contaminante en el Río Sonora, una 'mancha' que no se borra, available at:http://expansion.mx/?internal_source=MEGAMENU_SECTION

[26] Coloma López, P., Sánchez Navarro, J.A. \& Martínez Gíl, F.J., Sistemas de flujo subterráneo regional en el acuífero carbonatado mesozoico de la Sierra de Cameros. Sector oriental. Estudios Geológicos, 53, pp. 159-172, 1997.

https://doi.org/10.3989/egeol.97533-4240

[27] Kresic, N., Hydrogeology and groundwater modeling. CRC Press, FL USA. 807 pp. 2007.

[28] Gleick, P.H., Basic water requirements for human activities: Meeting basic needs. Water International, 21, pp. 83-92, 1996. https://doi.org/10.1080/02508069608686494

[29] SEMARNAT-IMTA, Precio del Agua: Subsector agua potable, alcantarillado y saneamiento, Proyecto DP-1330.1. Instituto Mexicano de Tecnología del Agua, Mexico. $36 \mathrm{pp}, 2013$.

[30] INEGI. Available at: http://www.inegi.org.mx/sistemas/bie/cuadrosestadisticos/Genera Cuadro.aspx? $=$ est $\& \mathrm{nc}=583 \& \mathrm{c}=29478$.

[31] SAGARPA, 3er Informe de Labores 2014-2015. Secretaría de Agricultura, Ganadería, Desarrollo Rural, Pesca y Alimentación. México. 148 pp. 2015.

[32] El Financiero. Available at: http://www.elfinanciero.com.mx/economia/un-gigante-expo rtador-de-alimentos.html. (Accessed 30 January, 2017).

[33] Shah, T., Groundwater and human development: challenges and opportunities in livelihoods and environment. Water Science and Technology, 51(8), pp. 27-37, 2005.

[34] Díaz-Padilla, G., Sánchez-Cohen, I., Guajardo-Panes, R.A., Del Ángel-Pérez, A.L., Ruíz-Corral, A., Medina-García, G. \& Ibarra-Castillo D., Mapping of the aridity index and its population distribution in Mexico. Revista Chapingo Serie Ciencias Forestales $y$ del Ambiente, V. XVII, Ed. Esp.: 267-275, 2011. 
[35] IT (International Transparency). Available at: http://www.transparency.org/news/ feature/corruption_perceptions_index_2016?gclid=CPj51_WE9dECFQ8taQodOaQKd

[36] IMCO (Instituto Mexicano para la Competitividad). Available at: http://imco.org.mx/ politica_buen_gobierno/mexico-anatomia-de-la-corrupcion/

[37] Hoekstra, A.Y., Methodological advancements in the footprint analysis. Ecological Economics, 68, pp. 1963-1974, 2009.

https://doi.org/10.1016/j.ecolecon.2008.06.021 